\title{
Vertebrojugular Arteriovenous Fistula and Pseudoaneurysm Formation due to Penetrating Vertebral Artery Injury: Case Report and Review of the Literature
}

\author{
Vertebral Arter Kesici Alet Yaralanmasına Bă̆lı Vertebrojuguler \\ Arteriovenöz Fistül ve Psödoanevrizma: Olgu Sunumu ve Literatürün \\ Gözden Geçirilmesi
}

Muhammet Bahadır YILMAZ ${ }^{1}$, Halil DONMEZ ${ }^{2}$, Mehmet TONGE ${ }^{3}$, Serkan SENOL ${ }^{2}$, Ayhan TEKINER ${ }^{1}$

${ }^{1}$ Kayseri Education and Research Hospital, Department of Neurosurgery, Kayseri, Turkey

${ }^{2}$ Erciyes University, School of Medicine, Department of Radiology, Kayseri, Turkey

${ }^{3}$ Cankir State Hospital, Department of Neurosurgery, Cankirn, Turkey

Corresponding Author: Muhammet Bahadır YILMAZ / E-mail: mbahadiryilmaz@yahoo.com.tr

\begin{abstract}
Vertebral artery injury including thrombosis, arteriovenous fistula (AVF), pseudo-aneurysm and hemorrhage may be iatrogenic or due to penetrating or blunt trauma. Although mostly asymptomatic, vertebral artery injury may also present with vertebrobasilar insufficiency findings, cephalgia, radicular pain or myelopathy due to blockade of arterial flow, arterial steal phenomenon and venous hypertension. The gold standard for diagnosis is digital subtraction angiography (DSA). Doppler ultrasonography, magnetic resonance-angiography and computerized tomography-angiography are also helpful. Endovascular treatment is now used more commonly. We present a case with sharp bread knife injury of the vertebral artery that was also complicated with a vertebrojugular fistula and pseudo-aneurysm together with the diagnostic and management options and a review of the current literature.
\end{abstract}

KEYWORDS: Vertebral artery, Penetrating injury, Vertebrojugular arteriovenous fistula, Pseudoaneurysm, Endovascular treatment

öz

Vertebral arter yaralanması tromboz, arterio-venöz fistül (AVF), psödoanevrizma ve hemoraji şeklinde görülebilmekte ve iyatrojenik nedenler, künt ve penetrantravmalar sonucu oluşabilmektedir. Çoğunlukla asemptomatik olmakla birlikte arteriyel akımda kesilme, arteriyel çalma ve venöz hipertansiyona bağlı vertebrobaziller yetmezlik bulguları, sefalji, radiküler ağrı ve miyelopati gibi bulgularla karşımıza çıkabilmektedir. Tanıda altın standart dijital substraksiyon anjiyografi (DSA) olmakla birlikte doppler ultrasonografi, manyetik rezonans anjiyografi ve bilgisayarlı tomografi anjiyografi de oldukça faydalıdır. Tedavide, günümüzde endovasküler tedavi cerrahinin önüne geçmiştir. Çalışmada hem keskin ekmek bıçağıyla vertebral arter yaralanması sonrası vertebrojuguler fistül ve psödoanevrizma gelişen hastayı, hem de vertebral arter yaralanmasında tanı ve tedavi seçeneklerini literatür eşliğinde sunulmaktadır.

ANAHTAR SÖZCÜKLER: Vertebral arter, Penetran travma, Vertebrojuguler arteriovenöz fistül, Psödoanevrizma, Endovasküler tedavi

\section{INTRODUCTION}

Injury of the vertebral artery is a rare problem that is almost always related with cervical penetrating and blunt trauma or iatrogenic reasons. Although some series report an incidence around $0.5 \%$ for blunt cervical trauma, this figure goes up to $17-46 \%$ when asymptomatic cases are considered (5, 27, 29). Trauma may result in pseudo-aneurysm formation, AVF, thrombosis or hemorrhage. Although the majority of vertebral artery injuries remain asymptomatic, they may also present with findings related to the cerebellum, brain stem and medulla spinalis. Vertebral artery injury findings may settle within a month with the compensating function of the contralateral vertebral artery and posterior communicating artery. Symptoms may also progress very quickly due to hemorrhage and may result in severe hypovolemia, shock and death. Treatment decisions must be made according to the localization and type of the lesion and the most appropriate choice among follow-up, surgery and endovascular intervention chosen. We present a case with stab injury to left vertebral artery at the $C 7$ level that presented with vertebrojugular AVF and pseudo-aneurysm in the absence of any neurological deficit with a review of the current literature. 


\section{CASE REPORT}

A 23-year-old male presented at the emergency department twenty minutes after being stabbed by a sharp bread knife at the left side of the neck. Examination showed no neurological deficit and his vital signs were stable. The hemoglobin levels remained stable during follow-up. Cervical computerized tomography (CT) and CT-angiography showed left transverse process fracture at $\mathrm{C} 7$ and injury of the left vertebral artery just before the entry point at the $\mathrm{C} 6$ vertebral foramen with an aneurysm-like appearance (Figure 1A). Repeated neurological examinations at the ICU showed no deterioration and the vital signs were all stable. There were no ischemic findings on brain CT. The patient was prepared for urgent digital subtraction angiography (DSA) but he refused the procedure and was discharged upon his request following placement of skin sutures. One week later, he came back for follow-up and a DSA was performed. The DSA revealed retrograde filling of the left vertebral artery due to an AVF proximal to the left vertebral artery on selective right vertebral arterial catheterization (steal phenomenon) (Figure 1B). Selective imaging of the right internal carotid artery also showed retrograde filling of the basilar artery via the posterior communicating artery (Figure 1C). Left subclavian imaging showed a high-flow vertebrojugular arteriovenous fistula (AVF) proximal to the vertebral artery (Figure 1D). Endovascular left vertebral arterial occlusion was proposed but the patient refused any intervention and was again discharged without treatment.

\section{DISCUSSION}

Vertebral artery injury is uncommon but well defined in the literature. It is mostly caused by cervical penetrating (firearm, knife, etc.) or blunt injury and by iatrogenic (catheterization, angiography, nerve block, spinal surgery, etc.) injuries. Blunt injuries are more frequent than penetrating injuries due to the sheltered anatomical nature of the vertebral artery that is surrounded by the bony cage of foramen transversarium and the cervical muscles $(6,17)$. Blunt cervical trauma may lead to dissection of the artery by stretching.

Intracranial portions of both vertebral arteries unite and form the basilar artery and also supply blood to the medulla spinalis. Alterations in vertebral arterial flow may therefore result in ischemic damage to the cerebellum, brain stem and medulla spinalis. Unilateral vertebral artery occlusions usually remain asymptomatic in healthy individuals with sufficient intracranial and extracranial collateral circulation, and a wellfunctioning polygon of Willis and contralateral vertebral artery. Some MRI series report an incidence of asymptomatic unilateral vertebral artery occlusion around $19 \%$ in blunt cervical trauma patients $(6,10)$. This suggests that the real incidence of vertebral artery injury is significantly higher than assumed.

The first anatomical portion of the vertebral artery arises from the subclavian artery and ends at the entry point to the C6 foramen transversarium. This portion is less vulnerable to blunt trauma as it is mobile and further away to bony structures $(29,34,35)$. The second portion passes through the foramina and is at more risk of injury with blunt trauma leading to fracture and dislocations. (29) Likewise, the third (intracranial) portion is also more vulnerable to blunt trauma following damage to surrounding bone and ligaments (13, 29).

A relationship between blunt cervical traumas leading to instability and vertebral artery injury is well established (5). Facet fracture, dislocation and fracture of the transverse foramen are considered to be risk factors in such injuries. Some authors accept facet fracture between the C2 and C6 levels as the most prominent risk factor for vertebral artery injury and strongly recommend proving the absence of any vertebral artery injury in these patients (5). A study by Chung et al. including 91 C2-6 vertebral trauma cases reported that 18 asymptomatic patients (19.8\%) showed complete vertebral artery occlusion due to intramural thrombosis. A total of 17 patients had facet fracture, 11 had transverse foramen fracture (10 posterior wall and 1 anterior wall) and 8 had facet dislocation. There were 73 patients without any vertebral artery injury who presented with transverse foramen fractures ( $n=16 ; 3$ anterior wall, 4 transverse and 9 posterior wall). However, this study showed no significant relationship between patients' Frankel grade and vertebral artery injury. There was a statistically significant association between vertebral artery injury and facet fracture, locked facet and transverse foramen fracture. Fractures of the posterior wall of the transverse foramen and unilateral locked facets have been found to be most risky for vertebral artery injury. A facet fracture was present in $94.4 \%$ of all patients with vertebral artery injury (VAl) and $41.4 \%$ of facet fracture patients had VAl. This study also used a VAl-risk score system that gave one point to each of unilateral locked facet, facet fracture and fracture of the posterior wall of the transverse foramen. Vertebral artery injury was 180 times more common in patients with a score of 3 points (5).

Many studies suggest transverse foramen fracture and especially unilateral facet dislocation as a major risk factor for $\operatorname{VAI}(5,22,33-35)$. Vertebral artery injury rates of $46 \%$ for middle cervical region traumas accompanied with facet injury and up to $88 \%$ for fractures including the foramen transversarium have been reported $(29,34,35)$. One must also keep in mind that $15 \%$ of patients have one hypoplasic vertebral artery as a variant, and this should not be considered an injury in posttraumatic angiography (5). The gold standard for diagnosis is therefore still a matter of debate. The high sensitivity of axial MRI sections for diagnosing dissection and thrombosis of the internal carotid artery is accepted $(5,23,28)$. Finally, the former study has shown no significant relationship between severity of trauma and VAl. While VAI mostly occurs with rotational traumas, serious neurological deficits occur following compression and hyperflexion traumas that do not correlate with the risk of VAI (5). In contrast, an 83-patient series by Torina et al. points to the relation between complete motor injury and thrombosis (31). 

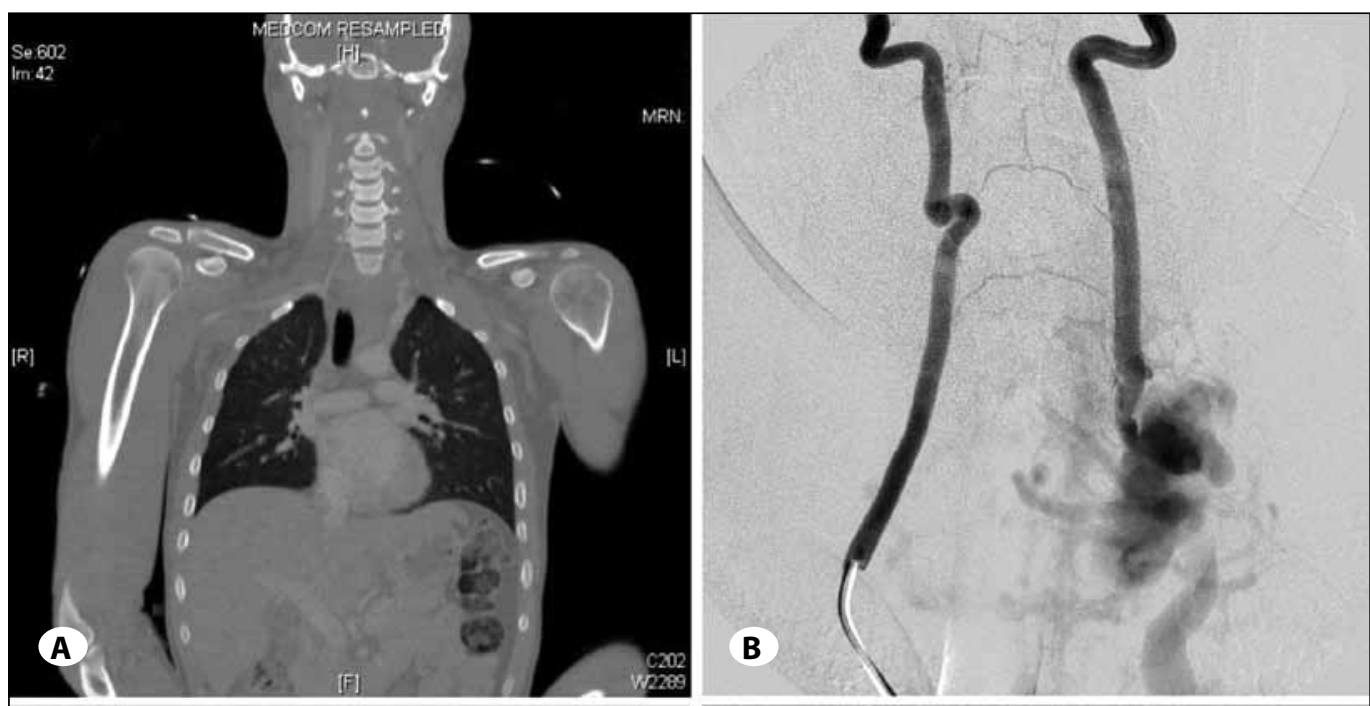

Figure 1: A) Cervical CT and CT-angiography showed injury of left vertebral artery just before the entry point at the $\mathrm{C} 6$ vertebral foramen with aneurysm-like appearance. B) A digital subtraction angiography was performed and revealed a retrograde filling of the left vertebral artery due to an AVF proximal to the left vertebral artery on selective right vertebral arterial catheterization (steal phenomenon). C) Selective imaging of the right internal carotid artery also showed retrograde filling of the basilar artery via the posterior communicating artery. D) Left subclavian imaging showed a highflow vertebrojugular AVF C proximal to the vertebral artery.

Vertebral artery injury may be accompanied by hemorrhage, stenosis, thrombosis, arteriovenous fistula and pseudoaneurysm formation. The concurrence of a vertebral artery pseudoaneurysm and arteriovenous fistula between the vertebral artery and internal jugular vein is extremely rare and mostly occurs following penetrating traumas of the craniocervical region or may be iatrogenic $(1,16,19,20,26)$. Penetrating traumas include firearm injuries while iatrogenic reasons include surgery, jugular venous catheterization, diagnostic angiography and nerve blocks (19). Synchronous injury of both the vertebral artery and jugular vein usually occurs at the level of the C1-2 lateral process $(14,19)$.

Most AVFs occur post-traumatically but congenital disorders such as fibromuscular dysplasia and neurofibromatosis may also create a predisposition $(7,11,20)$. Traumatic fistulas are mostly seen at the second part of the artery where it courses within the foramen transversarium (26). Although most cases have been reported below the $C 5$ level, Herrera et al. have found the majority of traumatic fistulas between C2-5 in their series (12). This is due to the high incidence of traumatic cervical injuries at the C2-5 levels. A fistula may arise between the extracranial branch of the vertebral artery and surrounding venous structures or radicular and muscular branches. Nearly $30 \%$ of AVFs are asymptomatic and diagnosed incidentally by auscultation of the bruit at the neck $(2,12)$. The disorder may result in vertebrobasilar ischemia, vertigo, diplopia and cephalgia due to arterial steal. Venous hypertension of dilated epidural veins caused by blood flow to spinal veins may result in root compression, pain and myelopathy $(8,12)$. We showed an AVF at the left vertebral artery where the vertebrobasilar system could not filled via left catheterization, but filled with right catheterization via the right posterior communicating artery (steal phenomenon) in our case.

Doppler ultrasonography, CT and CT-angiography are useful in emergent evaluation of probable vertebral arterial injuries. DSA is the gold standard for VAl but CT angiography and magnetic resonance (MR) angiography also provide good information. An MR scan is helpful for showing ischemic changes in the posterior fossa. Doppler USG is a cheap and non-invasive technique. It provides great data for patients with a bruit but being operator dependent can decrease its value. 
We prefer Doppler USG at first when a patient with penetrating neck injury present to our trauma unit. USG provides better evaluation of the anatomic structure of vasculature, flow speed and direction, the soft tissues and the perivascular hematoma if present. CT and CT angiography is then preferred. These investigations can show pathologies of vertebras adjacent to the lesion, the apexes of the lungs for pneumothorax, hematomas near the fistula, pseudoaneurysm and dilatation and tortuousity of venous structures due to AVF. CT angiography provides some data on vertebrobasilar continuity and the parenchyma. The third step of the diagnosis should be an MRI. The spinal cord and cerebral parenchyma are better visualized by MRI. Digital subtraction angiography should be considered as the fourth step when surgical or endovascular treatment is planned. In case of a stable and asymptomatic clinical course, color Doppler USG is preferable for periodic follow-up as it is cost effective and les invasive. USG provides great data regarding the amount, direction and speed of flow of the cervical vertebral arteries.

There are various treatment options. Emergent exploration was preferred for patients with firearm injury before the 90's but more detailed radiological examination is required these days. Eighty-percent of cervical firearm injury patients are believed to be eligible for conservative treatment and close follow-up $(6,32)$. Management of VAI due to cervical spinal trauma is still controversial. Many advocate that specific treatment is not required because the majority of patients remain asymptomatic (5). On the other hand, some cases end in severe neurological deficits of late onset and death $(3,5)$. Some authors therefore recommend aggressive antithrombotic treatment at the acute stage of cervical vertebra injury. However, such antithrombotic treatment for VAI may cause fatal hemorrhage and require further surgical intervention $(5,9)$.

The main goal in treatment is to protect the main artery and fix the fistula and pseudo-aneurysm. This goal is achieved more successfully by endovascular approaches using stents and grafts rather than surgical intervention. Surgical treatment of AVF includes proximal ligation, trapping and direct surgical closure. Surgical treatment is more difficult for vertebral AVF because of anatomical issues and difficulties in manipulation of the vessel. The surgery generally requires a large and complex exposure. The phrenic nerve and Batson's venous plexus are under great risk in interventions directed at the skull base (26). Surgery may cause damage in the surrounding main vascular structures and nerve roots (19). Endovascular interventions are now performed at many centers and are painless, more secure, less invasive, and provide relief quickly (26).

Treatment of AVF includes the occlusion of vertebral artery below and above the level of the fistula or direct closure of the fistula (26). This procedure may be performed via surgical ligation or endovascular techniques including stenting, detachable balloon, coil and other agents (14, 19, 20, 26).
These methods should be combined for some cases. These combinations are very important for the treatment of highflow fistulas. Another technique including closure of fistula orifice by micro-catheterization via the vertebral vein has also been described $(20,30)$. The total occlusion rates of up to $89-$ $91 \%$ have been reported for endovascular interventions $(2,12)$. Spontaneous occlusion is also not rare $(12,18)$. Surgery may be required for patients with severe hemorrhage or in whom the endovascular technique is unsuccessful. Using arterial occlusion is not possible for individuals whose contralateral vertebral artery is hypoplasic or has severely decreased flow due to atherosclerotic changes (26). The vertebral artery may be immature as a variant on $3.1 \%$ of the lesions on the left side and $1.8 \%$ on the right side $(21,26)$. Complication rates for vertebral arterial ligation around $8 \%$ and higher have been reported despite having sufficient collateral flow (21, 26). A $12 \%$ mortality rate has been reported for patients with acutely ligated vertebral artery during spinal surgery due to iatrogenic ruptures $(4,26)$. Some advocate endovascular reconstruction with coated stents in the presence of a patent artery $(15,20,25)$. If the damage is on the dominant vertebral artery, reconstruction with a stent and coil is mandatory. This is necessary to maintain the intravascular flow. Short-, middle- and long-term outcomes of AVF, pseudoaneurysm and dissection treatment with stenting seem encouraging (26).

Pseudoaneurysms located on the extracranial vertebral artery may spontaneously disappear or may be treated via occlusion of the parent artery. The pseudoaneurysm's lumen may also filled by embolic materials such as a stent and coil in selected patients $(19,26)$. Recurrence, constriction of stent or thrombosis may occur following treatment of an AVF or pseudoaneurysm. Anti-aggregant and anti-platelet medications are required to prevent these complications (26).

\section{REFERENCES}

1. Amirjamshidi A, Zafarghandy MR, Edraki K, Abbassioun K: Unilateral exophtalmus caused by traumatic vertebral artery to vertebral and jugular vein fistula: Problems in diagnosis and management. Brit J Neurosurg 13: 201-205, 1999

2. Beaujeux RL, Reizine DC, Casasco A, Aymard A, Rüfenacht D, Khayata MH, Riché MC, Merland JJ: Endovascular treatment of vertebral arteriovenous fistula. Radiology 183:361-367, 1992

3. Biffl WL, Moore EE, Elliott JP, Ray C, Offner PJ, Franciose RJ, Brega KE, Burch JM: The devastating potential of blunt vertebral arterial injuries. Ann Surg 231:672-681, 2000

4. Choi JW, Lee JK, Moon KS, Kim YS, Kwak HJ, Joo SP, Kim JH, Kim SH: Endovascular embolization of iatrogenic vertebral artery injury during anterior cervical spine surgery. Spine 31:891-894, 2006

5. Chung D, Sung JK, Cho DC, Kang DH: Vertebral artery injury in destabilized midcervical spine trauma; predisposing factors and proposed mechanism. Acta Neurochir 154: 2091-2098, 2012 
6. Dalgic A, Okay O, Nacar O, Daglioglu E, Pasaoglu L, Belen D: Vertebral artery insult at the transverse foramina by gunshot wounds: report of two cases. Turk Neurosurg 19:413-416, 2009

7. Deans WR, Bloch S, Leibrock L, Berman BM, Skultety FM: Arteriovenous fistula in patients with neurofibromatosis. Radiol 144:103-107, 1982

8. DeBray JM, Bertrand P, Bertrand F, Jeanvoine H: Spontaneous arteriovenous fistulas of the vertebral artery: Apropos of a case-review of the literature. Rev Med Interne 7:133-139, 1986

9. Fassett DR, Dailey AT, Vaccaro AR: Vertebral artery injuries associated with cervical spine injuries: A review of the literature. J Spinal Disord Tech 21:252-258, 2008

10. Giacobetti F, Vaccaro A, Bos-Giacobetti M, Deeley DM, Albert TJ, Farmer JC, Cotler JM: Vertebral artery occlusion associated with cervical spine trauma. A prospective analysis. Spine 22:188-192, 1997

11. Gobin YP, Duckwiller GR, Vinuela F: Direct arteriovenous fistulas (carotid-cavernous and vertebral-venous). Neuroimaging Clin N Am 8: 425-443,1998

12. Herrera DA, Vargas $S A$, Dublin AB: Endovascular treatment of traumatic injuries of the vertebral artery. AJNR Am J Neuroradiol 29:1585-1589,2008

13. Hinse $P$, Thie A, Lachenmayer L: Dissection of the extracranial vertebral artery: Report of four cases and review of the literature. J Neurol Neurosurg Psychiatry 54: 868-869,1991

14. Hung CL, Wu YJ, Lin CS, Hou CJ: Sequential endovascular coil embolization for a traumatic cervical vertebral AV fistula. Catheter Cardio Inte 60:267-269, 2003

15. Huttl K, Sebestyen $M$, Entz L, Molnár AA, Nemes B, Bérczi V: Covered stent placement in a traumatically injured vertebral artery. J Vasc Intervent Radiol 15: 201-202, 2004

16. Inamasu J, Guiot BH: latrogenic vertebral artery injury. Acta Neurol Scand 112:349-357, 2005

17. Jean WC, Barrett MD, Rockswold G, Bergman TA: Gunshot wound to the head resulting in a vertebral artery pseudoaneurysm at the base of the skull. J Trauma 50: 126- 128, 2001

18. Kubota M, Watanabe O, Takase M, Hashimoto T: Spontaneous disappearance of arte- riovenous fistula between the vertebral artery and deep cervical vein: case report. Neurol Med Chir (Tokyo) 32:84-87, 1992

19. Kurt A, Tanrivermis A, Ipek A, Tosun O, Gumus M, Yazicioglu KR, Tas I: A challenging problem. Vertebral pseudoaneurysm and arteriovenous fistula involving vertebral artery and ipsilateral internal jugular vein due to craniocervical penetrating trauma. Interv Neuroradiol 12(2):171-175,2006

20. Mortimer A, Stubbs E, Cookson D, Dawson R, Fleet M: Delayed presentation of a vertebral arterio-venous fistula secondary to penetrating cervical trauma: Endovascular management using coil embolisation - a case report. J Radiol Case Rep $3(6): 9-15,2009$
21. Mourikis D, Chatziioannou A, Doriforou O, Skiadas V, Koutoulidis V, Katsenis K, Vlahos L: Endovascular treatment of a vertebral artery pseudoaneurysm in a drug user. Cardiovas Intervent Radiol 29:662-664, 2006

22. Oetgen ME, Lawrence BD, Yue JJ: Does the morphology of foramen transversarium fracture predict vertebral artery injuries? Spine 33:957-961, 2008

23. Ozdoba C, Sturzenegger M, Schroth G: Internal carotid artery dissection: MR imaging features and clinical-radiologic correlation. Radiology 199(1):191-198, 1996

24. Sack JA, Etame AB, Shah GV, La Marca F, Park P: Management and outcomes of patients undergoing surgery for traumatic cervical fracture-subluxation associated with an asymptomatic vertebral artery injury. J Spinal Disord Tech 22(2):86-90, 2009

25. Sadato A, Satow T, Ishii A, Takayama M, Hashimoto N: Large vertebral arteriovenous fistula treated with stent-grafts-case report. Neurologia Medico- Chirurgica 43:250-254, 2003

26. Sancak T, Bilgic S, Ustuner E: Endovascular stent-graft treatment of a traumatic vertebral artery pseudoaneurysm and vertebrojugular fistula. Korean J Radiol 9:68-72, 2008

27. Schittek A: Pseudoaneurysm of the vertebral artery. Case report. Tex Heart Inst J 26(1):90-95, 1999

28. Sue DE, Brant-Zawaddzki MN, Chance J: Dissection of cranial arteries in the neck: Correlation of MRI and arteriography. Neuroradiology 34:273-278, 1992

29. Tekiner A, Gokcek C, Bayar MA, Erdem Y, Kilic C: Spontaneous resolution of a traumatic vertebral artery pseudoaneurysm. Turk Neurosurg 21:90-93, 2011

30. Tenjin H, Kimura S, Sugawa N: Coil embolization of vertebrovertebral arteriovenous fistula: A case report. SurgNeurol 63: 80-83, 2005

31. Torina PJ, Flanders AE, Carrino JA, Burns AS, Friedman DP, Harrop JS, Vacarro AR: Incidence of vertebral artery thrombosis in cervical spine trauma: Correlation with severity of spinal cord injury. AJNR Am J Neuroradiol 26:2645-2651, 2005

32. Van Deurzen DFP, van As AB, Verleisdonk EJMM: Is routine angiography necessary in patients with a gunshot wound to the neck? A retrospective analysis. Eur J Trauma 28: 90- 94, 2002

33. Veras LM, Pedraza-Gutierrez S, Castellanos J, Capellades J, Casamitjana J, Rovira-Cañellas A: Vertebral artery occlusion after acute cervical spine trauma. Spine 25:1171-1177, 2000

34. Willis BK, Greiner F, Orrison WW: The incidence of vertebral artery injury after midcervical spine fracture or subluxation. Neurosurgery 34:435-441, 1994

35. Woodring JH, Lee C, Duncan V: Transverse process fractures of the cervical vertebrae: Are they in significant? J Trauma 34: 797-802, 1993 